\title{
Russia-United Kingdom Diplomatic Crisis over Salisbury Nerve Agent Attack: An Analysis
}

\author{
Kingsley Chinonso Mark \\ Correspondence: Kingsley Chinonso Mark. Department of Political Science, Faculty of Social Sciences, Nnamdi \\ Azikiwe University Awka, Anambra State, Nigeria. E-mail: markkingsley11@ yahoo.com
}

Received: April 16, 2018 Accepted: June 4, 2018 Online Published: June 11, 2018

doi:10.11114/ijlpa.v1i1.3357

URL: http://dx.doi.org/10.11114/ijlpa.v1i1.3357

\begin{abstract}
Russia-United Kingdom Diplomatic ties have been banter of ally-crises-ally relations and have not fared well since its first diplomatic contact in 1553 during the era of Tsardom of Russia, and currently at its most tensed point occasioned by the alleged poison attack on Sergei Skripal in Salisbury. While it remains unclear which exactly of the Novichok variants were used to poison Skripal and his daughter? The medical effect of the poison is well understood and Britain with their allies points at Russia as the culprit. This single act has turn sour the diplomatic relations of these great powers. However, it raised multiplicity of arguments among scholars and analysts, who try to highlight and analyse views on who seeks to gain from the cold war between the power megalomaniacs. It is on this ground that the paper looks at the diplomatic crisis between Russia and United Kingdom over the attempted poisoning of Skripal and his daughter. The paper employed a combination of Psycho-Cultural Theory of Conflict and Conspiracy theory as it framework, using a qualitative analysis which relies on secondary data as its source of information to explore the problematic. It further examined if there were any similarities between the Salisbury attack and other attacks carried out in United Kingdom. The paper concludes with the implications of the attack, notes that despite Russia-United Kingdom crisis prone diplomatic relation over Salisbury nerve agent attack, they have an obligation to cooperate in the United Nation should an international conflict arise, as they encompass two of the five permanent members in the UN Security Council giving them the power to veto the approval of UN Security Council resolutions should any quick decision be required. Hence, the pronged disagreement is an interruption to the adoption of quick resolutions, particularly with the emergent danger of conflict and crises on the Korean headland and the on-going civil turbulence in Syria. The paper recommends among others; for Putin to take the opportunity of a new term to start afresh and rebuild ties with the United Kingdom, following the full dictates of diplomatic principles.
\end{abstract}

Keywords: Diplomats, Diplomacy, Diplomatic Crisis, Attack

\section{Introduction}

Russia-United Kingdom diplomatic crisis has over the years remained unabated since its first diplomatic tie in 1553 during the era of Tsardom of Russia. They established relations when the English navigator Richard Chancellor arrive Arkhangelsk at which time Mary I ruled England and Ivan the Terrible ruled Russia. Their relation transforms with changing times and state structure-system. It often switched from the state of alliance to rivalry or even war. Russia and Britain were ally against Napoleon, and enemies in the Crimean war of the 1850s, and rivals in the Great Game for the control of central Asia in the late $19^{\text {th }}$ century. They were allies again in World War 1 and 2, although the relation was strained by the Russian Revolution of 1917. They were at swords point during the Cold war (1947-1991) (Duncan, 2017).

In 1697-1698 during the Grand Embassy of Peter I, the Russian Tsar visited England for three months; he improved relations and learned the best new technology especially regarding ships and navigation. Their relations kept with the changes in the international system and their individual state structure. The kingdom of Great Britain (1707-1800) and later the United Kingdom of Great Britain and Ireland(1800-1922) had increasingly important ties with the Russian Empire (1721-1917), after Tsar Peter invited British engineers to saint Petersburg leading to the establishment of a small but commercially influential Anglo-Russian expatriate merchant community from 1730-1921(Duncan, 2017). From 1820-1907, a new element emerged: Russo phobia the British elite soppiness turned increasingly unfriendly to Russia, with the high degree of anxiety for the safety of India, with fear that Russia will push south through Afghanistan. Both countries intervened in the Greek war of independence (1821-1829), eventually forcing the London peace treaty 
on the belligerents. The events heightened Russo phobia. Rivalry between Russia and Britain grew steadily over central Asia in the great game of late $19^{\text {th }}$ century (Rodric, 2011). Russia desired warm water ports on the Indian Ocean while Britain wanted to prevent Russian troops from gaining potential invasion route to India.

Russia-United Kingdom Diplomatic ties became delicate in the early $20^{\text {th }}$ century. Russia was troubled by the Entente Cordiale between Great Britain and France signed in 1904. Russia and France already had a mutual defense agreement that France was obliged to threaten with an attack if Britain declare war on Russia (Duncan, 2017), their relations kept fluctuating until the $21^{\text {st }}$ century with the collapse of USSR. In the $21^{\text {st }}$ century however, while trade and human ties proliferated, diplomatic ties have suffered due to allegations of spying, and extradition disputes; thus escalating political tensions between London and Moscow. The recent is the poisoning of Sergei Skripal and his daughter Yulia in Salisbury, United Kingdom. This incident has drawn the two countries into serious diplomatic crisis, leading to the expulsion of diplomats from both sides.

The Russian state has been severally accused by the United Kingdom of having a hand in series of high profile assassinations and attempted murder of Russian dissents and those considered as enemies of the state in United Kingdom. There are many of such cases which are yet to be resolved and which bore same semblance to the recent attempted poisoning of Sergei Skripal and his daughter Yulia in Salisbury United Kingdom on $4^{\text {th }}$ march 2018. According to the British government, Skripal and his daughter Yulia were poisoned with a military grade nerve agent of a type produced by Russia, and that it was part of a group of agents known as 'Norvichok'. They argues that Russia has previously produced the agent and would still be capable of doing so, and that Russia has a record of conducting state sponsored assassinations seeing defectors as legitimate targets.

Sergei Skripal, a former colonel in the Russia's Main Intelligence Directorate (GRU), and worked as a double agent for the UK's Secret Intelligence Service from 1995 till his arrest in Moscow in December 2004. He was convicted of treason in his country for betraying agents to Britain's M16 secret service and sentenced to 13 years in penal colony. He moved to Britain in 2010 spy swap between Russia and U.K. This is one of too many of these incidents and have caused serious diplomatic crisis between the two countries leading to expulsion of diplomats on both sides, and even drawing their allies into it. Most of the previous cases went unresolved with both states accusing each other of interference and even carrying out the poisoning act.

As the Russia-United Kingdom Cold War-era barbs over the poison attack on ex-spy Sergei Skripal, it remains unclear which exactly of the many Novichok variants were used to poison Skripal and his daughter. Tests carried out by Defence Science and Technology Laboratory at Porton Down concludes that they had been exposed to a nerve agent. Both $\mathrm{Mr}$ and Miss Skripal remain in hospital under heavy sedation. The precise effect of their exposure on their long term health remains unclear albeit medical tests indicate that their mental capacity might be compromised to an unknown and so far unascertained degree (Justice Williams, 2018) [EWCOP 6; Case No: 13228376 \& 13228382]. However, despite the dictates of diplomacy and diplomatic principles which serves to direct the action and interaction of states relations, scholars have argued who seeks to gain from this cold war between Russia and United Kingdom.

The basic thrust of this paper therefore; is to examine the diplomatic crisis between Russia and United Kingdom over the attempted poisoning in Salisbury on $4^{\text {th }}$ of March 2018. Specifically, it examines similarities between the Salisbury attack and other attacks that are allegedly carried out in the states. The study is based on qualitative analysis which relies on secondary data as its source of information. This include: internet sources, books, newspapers, journals, among others. Be that as it may, the paper is divided into six sections. Section A deals with the introduction. Section B focuses on conceptual architecture. Section C is concerned with theoretical direction and Section D deals with Salisbury nerve attack and Russia-United Kingdom diplomatic crisis; cases of alleged Russia killings and attempted murders in United Kingdom. While section E centers on the implications of Salisbury nerve agent attack on Russia-United Kingdom Diplomatic crisis, section F focuses on the conclusion and recommendations.

\section{Conceptual Architecture}

Diplomacy is a concept derived from the ancient Greek word diploma, composed of diplo, meaning "folded in two", and the suffix-ma, meaning "an object". The folded documents confer a privilege often a permit to travel on the bearer (Bjola, 2015). There has not been any documented start of diplomacy; however there have been instances ranging back to the $5^{\text {th }}$ century where diplomacy arose in certain nations. Dating back to $432 \mathrm{BC}$, the congress of Sparta was an illustration of diplomacy as organized by the Greek city states. Nicolson (1977), notes, diplomacy is neither the invention nor pastime of some particular system, but is an essential element in any reasonable relation between man and man and between nation and nation. The treaty of Westphalia in 1648 created the first modern diplomatic congress in addition to creating a new world order in Europe which latter spread all over the world, and is based on sovereignty (Adler-Nissen, 2015).

From the above therefore, diplomacy as used by states in their relations with each other has generated a lot of debates at 
the local, national, and international levels among scholars, governments, corporate bodies and individuals. It has been perceived and interpreted in different forms by different scholars. According to Palmer and Perkins (2007:84) "No general definition of diplomacy can be very satisfactory or very revealing". In support of this view, Okafor and Chiamogu (2012) posits that "Diplomacy is a word that does not enjoy consensus among scholars. It means different things to different people and yet, it is frequently used by many in all areas of academic discourse". From the foregoing, the Oxford English Dictionary defines diplomacy as 'the management of international relations by negotiation,' or 'the method by which these relations are adjusted and managed'. A charming characterization, though vague and inadequate, is given in Sir Ernest Satow's Guide to Diplomatic Practice. He opined that "Diplomacy" is the application of intelligence and tact to the conduct of official relations between the governments of independent states.' Therefore, if there is the absence of intelligence and tact in the relations between states, is diplomacy impossible? It is on this ground that Sharp (2009) opines:

"Diplomacy is both conventional and easy to pose an antagonistic relationship between states. As it seek to hold the existing world together at almost any price, not underrating its capacity to tear states apart. The Irish socialist revolutionary James Connolly, writing on diplomacy and Speaking of British diplomacy in particular, refers to it as hypocrisy incarnate. He continues, Diplomacy has a code of honour of its own, has a standard by which it tests all things. That code has no necessary relation to the moral code, that standard has nothing to do with the righteousness of any cause. The diplomat holds all acts honourable which bring him success; all things are righteous which serve his ends. If cheating is necessary, he will cheat; if lying is useful, he will lie; if bribery helps, he will bribe; if murder serves, he will order murder; if burglary, seduction, arson or forgery brings success nearer, all aimed at actualizing stated objective" (Sharp, 2009:19).

Obviously, diplomacy is a tool use by States to determine disputes, form alliances, negotiate treaties, strengthen economic relations, promote cultural and military exchanges, and for a variety of other purposes (Berridge, 2010). It encapsulates a broad arrangement of shifting rules, etiquette, goals, procedures, and agreements. There are international laws that govern some aspects of diplomacy, while other elements are based on tradition, pragmatism, and expediency. Non state actors-including but not limited to nongovernmental organizations and multinational corporations play an increasingly important role in diplomatic relations as the tides of globalization shift the international landscape. Yet, no matter how much the international arena changes, diplomacy will always play a central role in dictating how states and other entities interact. The growing misconceptions of States in diplomatic relations have brought this view to question. Literature quite enormous, wide-ranging and diverse, but failed to structure the dictum of diplomatic interaction. However, some of the more specialized works dealt specifically on diplomacy and its negotiating cum persuasive variables.

To this end, diplomacy is an established method of influencing the decisions and behaviour of foreign governments and people through dialogue, negotiations, and other measures short of war or violence (Acuto, 2011). Berridge (2010), add that Diplomacy takes place in both bilateral and multilateral contexts. Bilateral diplomacy is the term used for communication between two States, while multilateral diplomacy involves contacts between several States often within the institutionalized setting of an international organization. He further notes that Diplomacy is the conduct of foreign relations by sovereign states through peaceful means. The nation state is the primary actor in the international relations and diplomacy is an instrument of state craft. As stated earlier, the peace of Westphalia of 1648 which marked the beginning of modern system of nation states, initiated the establishment of modern diplomacy (Dinesh (2016). Writings on diplomacy by De Callieres, Satow and Wicquefort as well as those of Nicolson, Kissinger and Berridge espouse the centrality of states in diplomacy (Kissinger, 1994). On that note, Berridge (2001) defines diplomacy as official channels of communication employed by members of a system of states, it is also the conduct of relations between sovereign states through the medium of officials based at home and abroad, the latter being either members of their states diplomatic service or temporary diplomats (Berridge and Berridge, 2003). Nicolson quoted by Holsti, (2004), sees diplomacy as an ordered conduct of relations between one group of human beings and another group alien to themselves and means of their interaction.

In a broader perspective, Griffiths and Roach (2008) captured diplomacy thus:

"the entire process through which states conduct their foreign relation. A means for allies to cooperate and for adversaries to resolve conflicts without force. States communicate, bargain, influence one another, and adjust their differences through diplomacy. It is interesting to note that serious confrontations between the great powers since 1815 have ended in force only about 10 per cent of the time. The routine business of international affairs is conducted through the peaceful instrument of diplomacy. In a more narrow sense, diplomacy is the implementation of foreign policy, as distinct from the process of policy formation. Diplomats may influence policy, but their main task is to negotiate with the representatives of other countries. Ambassadors, ministers, and envoys are official spokespersons for their country abroad and the instruments through which states 
maintain regular direct contact. Although messages are rapidly transmitted from one state to another today, personal, face-to-face encounters can put a stamp of privacy and authenticity on diplomatic exchanges. Formal diplomacy is a regularized system of official communication between states: the exchange of ambassadors, the maintenance of embassies in foreign capitals, the dispatch of messages through officially accredited emissaries, participation in conferences and other direct negotiations" (Griffiths \& Roach, 2008:80).

He further assets that the importance of diplomacy arises from the fact that most foreign policies are stated very generally, without spelling out measures for implementation. A good diplomat must adapt such policy mandates to the circumstances of the moment. Moreover, there are numerous occasions when the demands of a particular situation might justify an exception to policy, and for this a state often relies on the wisdom of its diplomatic officers in the field. Few governments pursue a perfectly consistent policy that is articulated with a single voice. It falls to the diplomats to reconcile the competing voices and to give coherence, emphasis, and interpretation to their state's foreign policy (Griffiths and Roach, 2008).

To the extent of the foregoing, diplomacy has two faces. It is the vehicle through which a state asserts itself and represents its concerns to the world; it is also one of the principal means for conciliating competing national interests. In other words, diplomacy aims to further a state's particular goals whilst preserving international order. It is the tool that states use to get their way without arousing the animosity of other states. Diplomats must constantly balance the needs to protect their state's interests and to avoid conflict with other states. Griffiths \& Roach (2008) in their view captures the functions of diplomats in the international system to include: intelligence gathering, image management, and policy implementation. An embassy gathers information on the thinking of the local political leadership, the state of the local economy, the nature of the political opposition, all of it critical for predicting internal problems and anticipating changes in foreign policy. Diplomatic representatives are the 'eyes and ears' of their government; their cables and reports form part of the raw material from which foreign policy is developed. Diplomacy also aims at creating a favourable image of the state. Modern communication makes it possible to shape perceptions and attitudes around the globe. States today have vast public relations apparatuses whose purpose is to place their actions and policies in a favourable light. Foreign embassies supply local news media with official interpretations and try to avoid negative publicity or explain it away. Finally, diplomats administer the overseas programmes of the state. They negotiate military basing rights, facilitate foreign investment and trade, supervise the distribution of economic aid, and provide information and technical assistance (Griffiths and Roach, 2008:81).

Contrarily, some scholars argues that in recent times, "there has been a manifest decline in the importance of diplomacy orchestrated by globalisation and its information and communication technology. In the days when travel and communications were primitive, diplomats had a great deal of authority and discretion in the implementation of foreign policy. They might be stationed abroad for many years without receiving new instructions or returning home. Today overseas envoys receive large numbers of cables and instructions on a daily basis. Heads of state communicate directly with one another by telephone. Top policymakers often negotiate directly with each other (summit diplomacy) or they send special envoys (shuttle diplomacy). On the other hand, the growth of interdependence among states, and the expansion of the old Eurocentric state system into a global international society, has brought in its wake the emergence of an increasingly multilateral style of diplomacy, with its multifaceted approaches at problem solving mechanisms which most often conflict with another" (Griffiths \& Roach, 2008:81), hence the act of negotiations seems a herculean task, calling for a win-win basis as in the case of Russia-United Kingdom diplomatic relations which has drawn the attention of scholars and analysts demanding frontward as diplomats only seeks to spread their countries political objectives, economic interests and cultural ideologies to other states, thereby having a foot hold in that state. It is on that note that Sharp (2009), adds

"Diplomats are defenders and beneficiaries of the present international arrangements. It is they who, day by day, undertake the work, practice the deceptions and create the spectacle of a world divided into sovereign states by which the divisions or apparent divisions between peoples and between people and their real interests are maintained. They are the enemy in two senses. First, and most obviously, diplomats and envoys are regarded as servants of those with power and influence. As such, they either support or take no position on the internal arrangements and processes by which their principals become and remain powerful and influential. Secondly, while diplomats may seek to advance the interests of their sovereigns at the expense of others, and may even help prepare the ground for violence to be used to serve these interests, they do so in such a way as to safeguard and perpetuate the understandings and conventions which make relations between the powerful and influential possible. They tempt their principals into taking terrible risks or shirking great moral responsibilities in order to serve the needs of some dark conception of domestic or international order. While they may be enemies of revolution, however, the overall view is that diplomats are symptoms, not causes, of what the revolutionary is up against, and servants of the real enemy" (Sharp, 2009:19). 


\section{Theoretical Direction}

The Psycho-Cultural theory of Conflict is employed in this paper to address the instinct and drive behind states action in the face of crises and conflict situations. The Psycho-Cultural Theory of conflicts contends that psychological, religious and other cultural and identity-based contradictions are the bases of crises among states (Mark, 2017).

The proponents of this theory include inter alia, Ross, Faleti, Seymour and Northrop. Psycho-cultural conflicts take long time to resolve because in this kind of conflict/crises, passion for the protection of one's identity, religion, culture and state overwhelms reason and inflames conflictual behaviours. Identity is an unshakeable sense of self-worth, which makes a life meaningful and includes the feeling that one is physically, socially, psychologically and spiritually safe. Hence, Northrop opines that "events which threaten to remove the feeling of safety that is tied to different forms of identity usually lead to defensive reactions aimed at avoiding such spiritual and physical exposure". Seymour emphasizes that identity influences the process of conflict and must not be overlooked when attempting to understand states relations and when planning diplomatic negotiations.

The quests for power and dominance have seen states unleash new behaviours. Sometimes, the recipients of these behaviours are piqued when they feel they are being robbed of their rights, which in some cases can arise as a result of losing the life of their citizens and acts of xenophobia, Russo-phobia which many a time lead to crises and violent revolts (Oguejiofor, 2016).

In the case of Russia-United Kingdom Diplomatic crises, it is perhaps ironic that United Kingdom has been threatened by the intrusion of fear in the form of poisoning attack of $4^{\text {th }}$ march 2018, against Sergei Skripal and Yulia in Salisbury United Kingdom. Hence United Kingdom feel threatened with contrary diplomatic actions and reactions. This aroused a sense of disenfranchisement and threatened their sense of safety between the two power Mongol-nations, taking to retrenchment of their diplomats.

\section{Conspiracy Theory}

Conspiracy theory is a justification of an incident that invokes an unwarranted conspiracy, generally one involving an illegitimate or injurious act carried out by government or other powerful actors. Conspiracy theories often produce hypotheses that contradict the prevailing understanding of history or simple facts (Nweke, 2018)

According to the political scientist Michael Barkun (2014), Conspiracy theories rely on the view that the universe is governed by design, and embody three principles: nothing happens by accident, nothing is as it seems, and everything is connected. Another common feature is that conspiracy theories evolve to incorporate whatever evidence exists against them, so that they become, as Barkun writes, a closed system that is un-falsifiable, and therefore "a matter of faith rather than proof" (Paterson, 2014)

\section{Types of Conspiracy Theory}

Jesse Walker (2013) identified five kinds of conspiracy theories: The "Enemy Outside" refers to theories based on figures alleged to be scheming against a community from without. The "Enemy Within" find the conspirators looking inside the nation, indistinguishable from ordinary citizens. The "Enemy Above" involves powerful people manipulating events for their own gain. The "Enemy Below" features the lower classes working to overturn the social order, then the "Benevolent Conspiracies" are angelic forces that work behind the scenes to improve the world and help people.

Barkun (2014), on his part, identified three classifications of conspiracy theory: Event conspiracy theories, this refers to limited and well-defined events. Examples may include such conspiracies theories as those concerning the Kennedy assassination, 9/11, and the spread of AIDS.

Systemic conspiracy theories, the conspiracy is alleged to have broad objectives, usually conceived as securing control of a country, a region, or even the entire world. The goals are sweeping, whilst the conspiratorial machinery is generally simple: a single, evil organization implements a plan to infiltrate and subvert existing institutions. This is a common scenario in conspiracy theories that focus on the alleged machinations of Jews, Freemasons, Communism, or the Catholic Church.

Super conspiracy theories; for Barkun, such theories link multiple alleged conspiracies together hierarchically. Murray Rothbard argues in favour of a model that contrasts "deep" conspiracy theories to "shallow" ones. According to Rothbard, a "shallow" theorist observes an event and asks Cui bono? ("Who benefits?"), jumping to the conclusion that a posited beneficiary is responsible for covertly influencing events. On the other hand, the "deep" conspiracy theorist begins with a hunch, and then seeks out evidence. Rothberg describes this latter activity as a matter of confirming with certain facts of one's initial suspicion.

Drawing from the above, the British Prime Minister Theresa May was plain in her address to parliament saying it was "now clear that Mr Skripal and his daughter were poisoned with a military-grade nerve agent of a type developed by 
Russia." The government has concluded that Russia was responsible for the act against Sergei and Yulia Skripal."

The worsening of tensions between Russia and the United Kingdom has also been reflected in the language used by Russian officials. After the British Defence Secretary Gavin Williamson said Russia should "go away and shut up", Russia's Defence Ministry spokesman Igor Konashenkov described it as "the speech-making of a bad-mannered woman from a bazaar". It can be deduced from the forthwith that the poisoning attack was a conspiracy by Russia against United Kingdom. Hence the conspirer and the conspiree can be said to have acted in defence of their states-interest not minding whose horse is gorge

\section{Salisbury Nerve Attack and Russia-United Kingdom Diplomatic Crisis}

On the $4^{\text {th }}$ of March, 2018, Sergei Skripal and his daughter Yulia were poisoned in Salisbury, England with a chemical determined by the Government of United Kingdom to be Novichok nerve agent. (Guardian, March 13, 2018), it should be noted that the nerve agent also affected the officer investigating the incident. The government of United Kingdom responded immediately with U.Ks prime minister issuing the Russian president an ultimatum to explain how a former spy was poisoned in Salisbury, otherwise she will conclude it was an " unlawful use of force" by the Russian state against UK. In a meeting of National Security Council, the prime minister told the MPs that it was "highly likely" that Russia was responsible for the attack on Segei Skripal and his daughter, Yulia. (Guardian, March 13, 2018). As noted in her statement to the House of Commons which triggered angry response from Moscow, the prime minister said the evidence had shown that Skripal had been targeted with a "military grade nerve agent of a type developed by Russia". Russia responded adequately, with their officials and spokeswoman for their foreign minister Maria Zakharova calling the remarks "a provocation" and describing the event as a "circus show in the British parliament" (Guardian, March 13, 2018).

Andrei Lugovoi, a Russian Member of Parliament accused of the 2006 murder of the former Russian agent, Alexander Litvienko, said May's decision to point the finger at Moscow so quickly was "at a minimum irresponsible". The tough statement's ensured the deepening of diplomatic row between Moscow and London. On the contrary as Guardian, March 13, (2018) notes, Jeremy Corbyn the UK labour leader warned against breakdown of communications with Moscow. To him, "we need to continue seeking a robust dialogue with Russia on all the issues currently dividing our countries, rather than simply cutting off contact and letting the tensions and divisions get worse and potentially even more dangerous". Thus, one can deduce the need for diplomacy to play its role in handling the situation and need for caution on both sides of the crisis.

To some scholars and analysts, the situation is an avenue for Russo phobic western media to make accusations that it was another example of Russia in general and Vladimir Putin in particular in disposing of a supposed enemy of the Kremlin (www.consortiumnews.com). According to James O'Neill's ' The Strange Case of the Russian Spy Poisoning, noted that the case is similar to the alleged Russian interference in the U.S presidential election that has little or no evidence and which is currently been investigated by Mueller. O'Neil raised certain issues in regards to the U.Ks accusation of Russia as the major culprit in the said poison attempt. Firstly, he asked; what are the known facts of which some have been accurately reported in the western mainstream media. The victim (assuming it was a deliberate attack upon him and his daughter) was formerly a colonel in the Russian military intelligence service (the GRU). The GRU as known is the largest Russian intelligence agency and as with its western equivalents, has a wide variety of functions, of which spying is only one of it.

In the early 1990s, Skripal was recruited by an M16 agent, Pablo Miller, whom the British media declined to name. Miller was an M16 agent in Tallinn, the capital of Estonia. Skripal was arrested in 2004. In 2006 he was convicted of treason and sentenced to prison. In 2010, he was released as part of a prisoner exchange deal with the Russians. He went to live in the United Kingdom where he has lived in supposed retirement ever since. Pertinent to note is that Salisbury where Skripal lived is only about 12 kilometers from Porton Down, the U.K's principal research center for nerve agents.

In contrary, James O'Neill's argues that if the Russians wanted to kill him, they had the opportunity to do so during the years when he was imprisoned. If they wished to kill him, it is not very credible that they would do so very publicly and by means that could not be bought off the shelf in the local pharmacy. This argument to an extent holds no water considering the case of Litivnenko in 2006.

A second major question asked in any criminal investigation is who benefits? According to James O'Neill's it is difficult to perceive a credible argument that Russia is a beneficiary of Skripals poisoning. Further support for the hypothesis that this was a false flag operation comes in the statement that British Prime Minister Theresa May made to the parliament. O'Neil noted that the statement is absurd and could only have been made when the intention was to further demonize and punish Russia, rather than attempt to establish truth and apply ordinary principles of evidence and factual analysis. 
The former British ambassador Craig Murray argues that the motive for the attempted murder of Skripal and his daughter was to further promote anti-Russian hysteria that inflicts western media and body politic. Murray argues that the same people who assured the world that Saddam Hussein had Weapon of Mass Destruction (WMD's) now assure you Russian 'novochok' nerve agents are being wielded by Vladimir Putin to attack people on British soil. He noted that a very vital missing word from Theresa May's statement was "only". She did not state that the nerve agent used was manufactured 'ONLY' by Russia. Rather she rather stated this group of nerve agents had been "developed by" Russia. He further noted that from Putin's point of view, to assassinate Skripal now seems to have very little motivation. If the Russians have waited eight years to do this, they could have waited until the world cup. Murray noted that Russians have never killed a swapped spy before. Just as diplomats , British and otherwise, are most ardent upholders of the principle of diplomatic immunity, so security service personnel everywhere are the least likely to wish to destroy a system which can be a key aspect of their own personal security.

In a divergent view, as published in the newyorker.com on March 13, 2018 notes that Russia definitely has a hand in the attack. They argued that with the Russian elections around the corner, which the powers within her confines, she would like to reassure the voting public that should the enemies of the state arise, they will be hunted down and punished, no matter where or when. Therefore, it should be bore in mind that Russia has a long sturdy tradition of portraying itself as being under siege, from within or without, and of reacting forcefully to any such threat. Not that Moscow has done anything as vulgar as confess to the Salisbury scheme. Instead, Russian media has dropped all manner of "coarse hints about the perils of the spying game." As Kirill Kleimenov posits "I don't wish death on anyone, but, for purely informative purposes, I have a warning for anyone who dreams such career". He presents Britain as a big Hoffa lump trap, into which unwary scoundrels are doomed to plunge.

In addition to the above, Alexander Litvinenko incident in the U.K, who had formerly been employed by the Russian secret service, and who was granted political asylum in Britain, in 2001, was poisoned on November 1, 2006 in a London hotel. It was established that the highly radioactive element polonium had been slipped into his tea. In 2014, Theresa May, who was then the home secretary announced a public inquiry into the death of Litvienko. The inquiry's report, published in January 2016 declared that the toxic offense had been "probably approved "by Vladimir Putin. David Cameron, then prime minister went further calling it "state sponsored murder".

Several State showed solidarity to the United Kingdom in this recent crisis by taking some diplomatic steps targeted at Russia; ranging from expulsion of Russian diplomats to threat to pull out from the forthcoming FIFA world cup billed to be hosted by Russia. The United States, British closest allies, expels more than 100 Russian officials from their national capitals in a coordinated diplomatic offensive aimed at isolating the kremlin for its alleged role in the poisoning of the former spy on UK soil. It should be noted that Donald Trump, was slow to link the nerve agent attack on Sergei Skripal to Moscow and has been criticized for trying to improve ties to the kremlin accounted for most of the expulsions, He gave 60 Russians in Moscow Washington embassy and UN mission one week to leave the country. US officials said they were intelligence officers operating under diplomatic cover. Theresa May might have recorded a significant diplomatic victory, after the US was joined by every NATO ally- including France, Germany, Italy, Poland and Canada in announcing Russian expulsions.

\section{Cases of Alleged Russia Killings and Attempted Murders in United Kingdom}

There are several cases of killings and attempted murders in the United Kingdom that alleged have the backing of Russia as in the case of Skripal and his daughter. Most of this cases were never resolved even though the accusations and counter accusations between the two states led to diplomatic crisis amongst them which took steps to show their displeasure in the events.

\section{Alexander Litvinenko}

There is a "strong circumstantial case that the Russian State was responsible for Mr Litvinenko's death". Alexander Litvinenko was a former FSB agent who, in November 1998, publicly accused the Russian state of planning to assassinate the businessman Boris Berezovsky (who himself died in 2013 and who is discussed in more detail below).He claimed that the Russian state was responsible for sponsoring domestic and foreign terrorism. In 2004, he alleged that the Russian secret services knew in advance about the Beslan school siege in which 334 people were killed. Mr Litvinenko fled Russia in 2000 and was granted asylum in the UK.

On $1^{\text {st }}$ November 2006, Alexander Litvinenko became ill as a result of exposure to the radioactive element polonium-210. He died on $23^{\text {rd }}$ November 2006. Mr Litvinenko made a statement on what became his deathbed, addressed to Russian president, Vladimir Putin. He said: "You may succeed in silencing one man but the howl of protest from around the world will reverberate in your ears for the rest of your life. May God forgive you for what you have done, not only to me but to beloved Russia and its people" On the $6^{\text {th }}$ of December 2006, Scotland Yard filed suit against Mr Litvinenko's death treating it as murder, it took October 2011 for an inquest to be scheduled. Sir Robert 
Owen, a high court judge, was the coroner in the hearing, which was due to start on 1 May 2013. Before the inquest began, the UK government submitted a Public Interest Immunity certificate, which meant they could exclude information held by the security services on possible Russian state involvement from the proceedings.

In July 2014, Theresa May, a Home Secretary at the time, announced that there would be a public inquiry - despite having previously ruled it out, apparently to avoid diplomatic problems with Russia. The public inquiry found in June 2016 that "Mr Litvinenko was killed at the direction of the FSB" and, in the view of Sir Robert, "the FSB operation to kill Mr Litvinenko was probably approved by Mr Nikolai Patrushev head of the security service in 2006 and also by President Putin." Dr Matthew Puncher, the radiation expert who was part of the investigation into Mr Litvinenko's death was himself found dead in 2016. He died as a result of multiple stab wounds. A pathologist said he could not exclude the possibility that someone else was involved, but he said that Dr Puncher's injuries were self-inflicted. Inquest into his death revealed that Dr Puncher had become "obsessed" with a miscalculation error he had made in a separate piece of research and feared he would be imprisoned for breaking a contract with the US government.

\section{Alexander Perepilichny}

Alexander Perepilichny was a "key witness against a network of corrupt Russian officials and crime figures known as the "Kluyev Group" (Telegraph). This was part of the "Magnitsky affair", named after Russian lawyer Sergei Magnitsky, who was hired by investors, Hermitage Capital, to investigate an alleged $£ 144$ million tax fraud scheme to which the firm had fallen victim. The alleged fraud was said to have involved Russian officials. Mr Magnitsky testified against the police, but was later charged with tax evasion himself. He died in prison. After Mr Magnitsky's death, $\mathrm{Mr}$ Perepilichny reportedly gave the Swiss authorities information that allowed them to open an investigation into the alleged fraud scheme. After Mr Perepilichny's death in 2012, the Independent reported that "a source with knowledge of the investigationmade known that "Perepilichny was the person who brought the evidence the Swiss authorities needed to open the investigation. He brought with him records of shell companies, Credit Suisse accounts, property transactions. Mr Perepilichnyy collapsed and died outside his home in Surrey after he had been jogging. Two autopsies proved inconclusive, as he did toxicology tests.

In 2015, a pre-inquest hearing into Mr Perepilichnyy's death heard that his life insurance company ordered tests that detected a toxin (from the gelsium plant) that is known to trigger cardiac arrest if ingested. The Guardian reported that a plant expert from the Royal Botanic Gardens in Kew, Professor Monique Simmonds,reached initial findings that $\mathrm{Mr}$ Perepilichnyy ingested poison. The hearing was also given evidence that he had received threats from Moscow. However, in June 2017, Mr Perepilichnyy's widow, Tatiana, told the ongoing inquest into his death that she did not believe her husband had been murdered and that there was nothing to suggest that he had received threats. The inquest into Mr Perepilichnyy's death is still open.

Official response from Surrey Police says Mr Perepilichnyy's death is not suspicious. In 2016, the Home Secretary, Amber Rudd, made an application for a Public Interest Immunity certificate. The certificate allows possible evidence from MI5 and MI6 to be excluded from the investigation. Buzz Feed report that "Secret documents and interviews with more than a dozen current and former intelligence and law enforcement officials in the US, France, and the UK reveal: "US spies said they have passed MI6 high-grade intelligence indicating that Perepilichnyy was likely 'assassinated on direct orders from Putin or people close to him'. A highly classified report on Russian state assassinations compiled for the US Congress by the Office of the Director of National Intelligence last year asserts with 'high confidence' that Perepilichnyy's murder was sanctioned by Putin, Russia's president. French police observed and treating the financier's death as a suspected organized assassination, but they have been repeatedly stonewalled by their British counterparts.

\section{Boris Berezovsky}

Boris Berezovsky was a Russian government official during the 1990s, rising to become deputy secretary of the country's Security Council. He was a member of Boris Yeltsin's "inner circle" during Yeltsin's time as Russian leader. He made his fortune, which in 1997, Forbes magazine estimated at \$3 billion, as a middleman importing Mercedes cars into the country. He left Russia in 2000 after the election of Vladimir Putin, of whom Mr Berezovsky was a vocal critic. He was convicted in absentia of fraud and embezzlement by the Russian state, and was granted asylum in the UK in 2003. In 2003, Alexander Litvinenko said that an FSB agent was planning to assassinate Mr Berezovsky. Hazel Blears, then minister at the Home Office, told Parliament that the claims of an assassination plot against Mr Berezovsky had been investigated and "Inquiries made were unable to either substantiate this information or find evidence of any criminal offences having been committed. Investigations into this matter have been concluded."

In 2007, the Metropolitan Police arrested a man in central London on suspicion of conspiracy to murder. The BBC reported that he was questioned in connection with an alleged attempt to assassinate Mr Berezovsky. Thames Valley Police said that a post-mortem found Mr Berezovsky's death was "consistent with hanging." He was found dead by an employee on his bathroom floor. The Guardian reported that a close friend of Mr Berezovsky had described him as 
"very, very low" and claimed he had taken antidepressants the year before his death and attended the Priory clinic while being treated for depression.

However, that same friend reportedly also said that they didn't believe Mr Berezovksy "had the courage to take his own life, he loved life too much." Detective Chief Inspector Kevin Brown said that there was no evidence to suggest third-party involvement in Mr Berezovsky's death. The coroner in charge of the inquest into Mr Berezovsky's death recorded an open verdict, concluding: "I am not saying Mr Berezovsky took his own life, I am not saying $\mathrm{Mr}$ Berezovsky was unlawfully killed. "What I am saying is that the burden of proof sets such a high standard it is impossible for me to say." He said that the inquest had heard contradictory evidence. The Home Office pathologist who carried out Mr Berezovsky's post-mortem, Dr Simon Poole, told the inquest that there was nothing to indicate anyone else's involvement in the death. However, Bernd Brinkmann, a professor of forensic science, gave apparently contradictory evidence, saying that the marks on $\mathrm{Mr}$ Berezovsky's neck were "not consistent with hanging"(www.channel4.com/news/factcheck-high-profile-deaths-on-british-soil-with-alleged-links-to-thekremlin).

\section{Conclusion and Recommendations}

Despite Russia-United Kingdom strained diplomatic relations, they have to agree to work together in the UN should a global crisis erupt. As there consist two in a five permanent seats of members on the UN Security Council, providing both the force of veto in the approval of UN Security Council resolutions. In the midst of any unanticipated and urgent emergency which may occur as a result of conflictual disaster, the bilateral clash could hinder the quick adoption of urgent resolutions. This is worrisome as the UN answers to issues of international crises, particularly in the midst of the increasing risk of crises on the Korean headland and the ongoing civil unrest in Syria. For the two countries to be in a good book of each other again, in terms of bilateral and diplomatic relations, it will require significant nurturing as the way out of their current diplomatic maladies. Although not all issues will be determined, some conciliation will be necessary to start a dialogue. Other issues are likely to follow; expect a mutual visit of the Russian foreign minister to the UK as a display of diplomatic upright.

The first issue that could be possibly resolve is Russia's interfering in the Brexit vote. Brexit discussions are still on-going, with sporadic achievement and the upward discontent of the Prime Minister's (Theresa May's) sectional government. Her conservative party split over the Brexit resolutions conceding that the vote was negotiated, which will further weaken her position. Therefore the issue is likely to settle down, but will always remain a reference point throughout Russia-UK talks. Therefore, the economic sanction is implausible to lift, hitherto, a decision that seem damaging to Russia's national interests. During the bilateral meeting in Moscow, Lavrov remarked that Russia had not committed any provable harmful actions against the UK that necessitate the sanctions. But Johnson's response was the invasion of Crimea is not a matter of direct national interest but rather a reflection of the reaction of the international community and the desire to maintain a global norm of non-occupation. As long as the UK seeks to indorse those values and be seen as a resolute member of the international community, London's attitude towards Russia's invasion of Crimea will not change. To this end, despite the sanctions, trade between Russia and the UK has not suffered significantly. At the start of 2017, there was a substantial increase in the trade on items, as indorsed under the sanctions, their exports and imports further justifies that London lack the necessities to immediately lift the sanctions.

With presidential elections over in Russia, it is very likely that the re-elected Putin will take the opportunity of a new term to start afresh and rebuild ties with the UK. Even in a state of ideological conflict, two nations will be able to work together at the diplomatic level. The extent to which they continue to undermine one another in other areas remains to be seen, hence can only do more harm than good within their states interests and among committee of nations.

\section{References}

Acuto, M. (2011) Diplomats in crises, Diplomacy \& State craft, 22:3, 521-539. Google Scholar, Crossref

Adler-Nissen, R. (2015). Opting out of the European Union : Diplomacy, Sovereignty and European Integration (Cambridge: Cambridge University Press). Google Scholar

Barkun, M. (2014). A Culture of Conspiracy: Apocalyptic Visions in Contemporary America. Berkeley: University of California Press. p.58.

Barkun, M. (2011). Chasing Phantoms: Reality, Imagination, and Homeland Security Since 9/11. Chapel Hill: University of North Carolina Press. p.10.

Berridge, G. R. (2001). Diplomacy Theory from Machiavelli to Kissinger”, New York, Palgrave.

Berridge, G. R., Berridge, J., \& Alan, A. (2003). A dictionary of diplomacy, 2nd edition, New York, Palgrave Macmillan 
Berridge, G. (2010), Diplomacy: Theory and Practice (4th edn) (Basingstoke: Palgrave Macmillan). Google Scholar, Crossref

Barry, E., \& Perez-Pena, R. (2018). Britain Says Russia Is Likely to Blame for the Poisoning of an Ex-Spy. (Foreign Desk)(Sergei V. Skrip The New York Times March 132018 Issue.

Bjola, C. (2015). Diplomatic leadership in times of international crisis: The maverick, the congregator and the pragmatist', Hague Journal of Diplomacy, 10:1, 4-9. Google Scholar, Crossref, ISI

Dinesh. (2016). Diplomacy: Meaning, Nature, Functions and Role in Crisis Management International Politics Advertisements.

European Union News. (2018). PM Commons statement on Salisbury incident: 12 March 2018. March 142018 Issue.

Griffiths, M., \& Roach, C. S. (2008). International Relations; the Key Concepts: Routledge Taylor and Francis Group.

Guardian, March 13, (2018). The-strange-case-ofthe-russian-spy-poisonin: www.guardian.com/2018/03/13/the-strange-case-ofthe-russian-spy-poisonin

Hoslti, K. J. (2004). Taming the sovereign in institutional change in international politics"Cambridge,. Cambridge University press.

Jacques, H. (2018). The Lugovoy Extradition Case, International \& Comparative Law Quarterly.

Jesse-Walker. (2013), Kinds of Conspiracy Theories: The "Enemy In \& Outside" LondonPublisher.

Kissinger, H. (1994). Diplomacy, New York, Simon and Shuster.

Murray, S. (2008). Consolidating the gains made in diplomacy studies: A taxonomy. International Studies Perspectives, 9(1), 22-39. https://doi.org/10.1111/j.1528-3585.2007.00314.x.

Nicholson, G. (1996). The ontological difference. American Philosophical Quarterly, 33(4), 357-374.

Oguejiofor, P. W. (2016). The US and the Emergence of Islamic State (IS): The Paradox of America's War on Terror. Journal of Pol Sci. and Pub Affairs s2. https://doi.org/10.4172/2332-0761.s2-001

Okafor, F. C., \& Chiamogu, P. A. (2012), Thoughts on International Relations. Lagos, Nigeria: Absolute Media Production.

Palmer-Perkins, H. C. (2007). International Relations: The World Community in Transition. Krishan Nagar Delhi, India: Virender Kumar Arya for A.I.T.B.S Publishers and Distributors (Regd).

Paterson, T. (2014). Ukraine crisis: Angry Angela Merkel questions whether Putin is "in touch with reality. The Telegraph, 3 March. Available online at: http://www.telegraph.co.uk/news/worldnews/europe/ukraine/10673235/Ukraine-crisis-Angry-Angela-Merkel-quest ions-whether-Putin-is-intouch-with-reality.html (Accessed 7 November 2014). Google Scholar

Pigden, C. R. (2007). Conspiracy Theories and the Conventional Wisdom. Episteme: A Journal of Social Epistemology, 4(2), 222. https://doi.org/10.1353/epi.2007.0017.

Sharp, P. (2009). Diplomatic theory of International Relations. New York, Melbourne: Cambridge University Press.

The Guardian. (2018). Issue Russians' view of spy poisoning: 'We are the world's scapegoat'; Salisbury nerve attack draws respond", (London, England), March 152018.

The Independent. (2018). Boris Johnson points blame at Putin over spy poisoning. (London, England), March 172018 Issue.

\section{Copyrights}

Copyright for this article is retained by the author(s), with first publication rights granted to the journal.

This is an open-access article distributed under the terms and conditions of the Creative Commons Attribution License which permits unrestricted use, distribution, and reproduction in any medium, provided the original work is properly cited. 